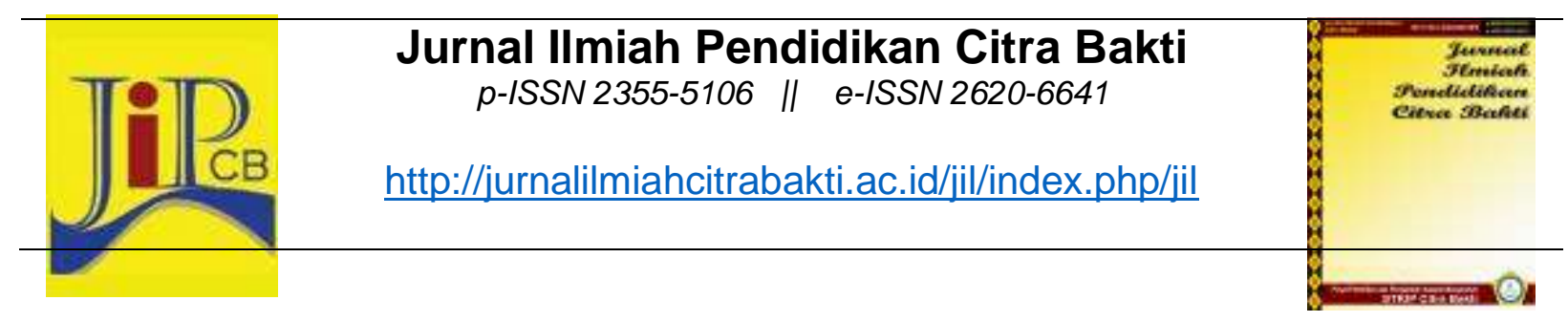

\title{
TINJAUAN PEMBELAJARAN VISUAL EKSPRESIF DALAM PROGRAM PENDIDIKAN INKLUSIF
}

\author{
Dian Kencana1), Mamat Supriatna²), dan Eka Sakti Yudha ${ }^{3)}$ \\ 1)Program Studi Pendidikan Seni, Universitas Pendidikan Indonesia \\ ${ }^{2,3)}$ Program Studi Bimbingan dan Konseling, Universitas Pendidikan Indonesia \\ 1)diankencana1970@gmail.com, 2)
}

\section{Histori artikel}

Received:

12 Agustus 2020

Accepted:

28 Oktober 2020

Published:

1 November 2020

\begin{abstract}
Abstrak
Penulisan ini bertujuan untuk menjawab tiga permasalahan, yaitu pengertian, unsur dan kegunaan pembelajaran visual ekspresif dalam program pendidikan inklusif berdasarkan hasil studi pustaka tentang tinjauan pembelajaran visual ekspresif dalam program pendidikan inklusif. Dalam mengkaji tiga persoalan tersebut, penulis menggunakan metode kajian pustaka dari beberapa sumber yang merupakan hasil penelitian baik dari buku teks, jurnal maupun artikel, melalui tahapan. 1) Menelaah hasil penelitian karya ilmiah yang terkait. 2) Mengklasifikasikan atau mengelompokkan konsep-konsep terhadap bahan-bahan bacaan. 3) Mendeskripsikan ulang dalam bentuk analisis 4) Menyajikan dalam bentuk tabel atau matriks 5) Mengambil saripati. Kegunaan hasil kajian ini dapat digunakan secara teoritis untuk pengembangan riset dan menambah keilmuan serta secara praktis adalah untuk membangun pemahaman bagi guru dalam bidang pembelajaran visual ekspresif dalam program pendidikan inklusif. Temuan penelitian ini adalah model hipotetik tentang pembelajaran seni rupa visual ekspresif dalam program pendidikan inklusif, yaitu siswa regular dan siswa disabilitas belajar bersama, berapresiasi, berekspresi, serta memiliki makna dalam kehidupan sehari-hari dalam bentuk pengetahuan, keterampilan dan sikap.
\end{abstract}

Kata kata Kunci: pembelajaran seni rupa, visual ekspresif, program inklusif 
Abstract. This writing aims to answer three issues about the definitions, elements and benefits of expressive visual learning in inclusive education program based on literature review of expressive visual learning observation in inclusive education program. In reviewing these issues, the author uses the literature review method from several sources which are the results of research both from textbooks, journals and articles, through the following stages. 1) Reviewing the results of related scientific works. 2) Classifying the concepts of reading materials. 3) Re-describe in the form of analysis 4) Present in the form of a table or matrix 5) Take the point. The usefulness of this study can be used theoretically for research development and adding to knowledge in the field of expressive visual learning also, practically to build understanding for teachers in the visual expressive learning in inclusive education programs. The findings of this study are a hypothetical model of learning expression visual arts in an inclusive education program, that means regular students and students with disabilities learn together, express, create, appreciate and have meaning in everyday life not only in the form of knowledge (conception) and skills (expression) but have meaning in the form of attitude (appreciation). The purpose of this study can be used theoretically for research development and adding to knowledge and it is practically to build understanding for teachers in the field of expressive visual learning in inclusive education programs. The findings of this study are a hypothetical model of learning expressive visual arts in an inclusive education program, which is regular students and students with disabilities learn together, appreciate, express, and have meaning in daily life in the form of knowledge, skills and attitudes.

Keywords: fine arts learning, visual expressive, inclusive programs

\section{Latar Belakang}

Pendidikan inklusif bermakna bahwa sekolah harus mengakomodasi semua anak tanpa mempedulikan keadaan fisik, intelektual, sosial, emosi, bahasa, atau kondisi-kondisi lain termasuk anak-anak disabilitas, anak-anak berbakat, pekerja anak dan anak jalanan, anak di daerah terpencil, anak-anak dari kelompok etnik dan bahasa minoritas, anak-anak yang tidak beruntung, dan terpinggirkan dari kelompok masyarakat (UNESCO, 2006).

Sekolah Inklusif menggabungkan kelas reguler dan anak berkebutuhan khusus. Melalui wadah pendidikan inklusif, anak yang memiliki kelainan dididik bersama-sama anak lainnya (normal) yang diharapkan dapat mengoptimalkan potensi yang dimilikinya. Anakanak memperoleh semua kompetensi yang mereka butuhkan untuk mengekspresikan diri dan bertahan hidup dalam masyarakat melalui Pendidikan. Salah satu pembelajaran yang mampu menumbuhkan ekspresi dan imajinasi anak adalah pembelajaran seni rupa.

Pembelajaran seni rupa adalah cara atau strategi menanamkan pengetahuan dan keterampilan, dengan cara mengkondisikan anak atau siswa menjadi kreatif, inovatif dan mampu mengenali potensi dirinya secara khas serta memiliki sensitivitas terhadap berbagai perubahan sosial budaya dan lingkungan (Kamaril, 2000).

Seni rupa murni merupakan seni yang dikembangkan untuk dinikmati keindahannya. Seni rupa murni mengutamakan sifat estetikanya dibandingkan kegunaanya. Seni rupa murni biasanya termasuk bentuk seni visual dan seni perform. Seni rupa murni erat kaitannya dengan bentuk seni visual, sehingga seni murni ini dapat disebut sebagai seni rupa visual ekspresif. 
Seni rupa murni atau visual ekspresif adalah salah satu jenis dari seni rupa yang mampu memberikan atau mengungkapkan gambaran dan perasaan, sehingga pembelajaran visual ekspresif dapat menjadi sarana untuk mengembangkan fleksibilitas, harga diri, komunikasi sosial, juga dapat mengekspresikan perasaan dan emosi siswa dalam program pendidikan inklusif (Simanis, 2019).

Salah satu mata pelajaran yang mempelajari tentang konsep-konsep dan nilai seni serta mengembangkan keterampilan untuk menghasilkan karya seni yang dapat dinikmati secara visual adalah seni rupa. Seni rupa juga merupakan sarana berekspresi bagi setiap individu untuk mengembangkan potensi jiwanya ke arah dewasa, baik secara rohani maupun sikap sosialnya, tenggang rasanya, tanggung jawabnya kepada masyarakat dimana dia tinggal, dan dewasa secara fisik berarti telah berkembang aspek-aspek keterampilan, yang tentu akan berguna dalam kehidupan kelak. Untuk mencapai tujuan pengembangan secara optimal sangat diperlukan strategi pembelajaran yang tepat guna (Kamsijo, 2009).

Pendidikan seni rupa juga penting dalam pendidikan inklusif agar siswa dapat berkembang secara normal serta dapat beradaptasi dengan kehidupan sosial, sehingga kualitas emosional, perkembangan persepsi, keterampilan ekspresif dan kreativitas mereka dapat ditingkatkan (Cevirgen 2018). Dalam hal anak-anak inklusif, tujuan utama pendidikan seni rupa adalah memberi peran pada perkembangan individu anak dan tidak sekedar menciptakan karya seni, tapi meningkatkan perilaku dan keterampilan yang ditunjukkan anak selama membuat karya. Pendidikan seni rupa sangat penting untuk pendidikan inklusif yang memiliki banyak cara untuk mengembangkan dan memungkinkan individu untuk mentransfer perasaan dan pikiran mereka dengan santai dan lingkungan yang damai. Seni rupa juga dapat membuat anak-anak menyadari diri mereka sendiri, berperan pada pengembangan anak-anak, dan dapat bertindak secara independen di bidang-bidang tertentu (Cevirgen 2018).

Berdasarkan uraian diatas, penulis melakukan kajian pustaka dari beberapa sumber studi pustaka yang diarahkan untuk menjawab beberapa permasalahan, yaitu apa yang dimaksud dengan pembelajaran visual ekspresif, bagaimana unsur pembelajaran visual ekspresif dan bagaimana kegunaan pembelajaran visual ekspresif dalam program pendidikan inklusif. Tujuan penulisan artikel ini adalah untuk memberikan penjelasan tentang pembelajaran visual ekspresif, unsur pembelajaran visual ekspresif, dan kegunaan pembelajaran visual ekspresif dalam program pendidikan inklusif. 


\section{Metode}

Penelitian ini menggunakan metode penelitian kajian pustaka atau studi kepustakaan yang berisi teori-teori yang relevan dengan masalah-masalah penelitian. Adapun masalah pada penulisan ini adalah untuk mengkaji "Tinjauan Pembelajaran Visual Ekspresif Dalam Pendidikan Inklusif."

Dalam studi pustaka dilakukan pengkajian mengenai konsep dan teori yang digunakan berdasarkan literatur yang tersedia, terutama dari artikel-artikel yang dipublikasikan dalam berbagai jurnal ilmiah. Kajian pustaka berfungsi untuk membangun konsep atau teori yang menjadi dasar studi dalam penelitian (Sujarweni, 2014).

Kajian pustaka atau studi pustaka merupakan salah satu kegiatan yang diwajibkan dalam penelitian, khususnya penelitian akademik yang tujuan utamanya adalah mengembangkan aspek teoritis maupun aspek manfaat praktis. Dengan menggunakan metode penelitian ini penulis dapat dengan mudah menyelesaikan masalah yang hendak diteliti. (Sukardi, 2013). Penulis menggunakan metode kajian pustaka dari beberapa sumber yang merupakan hasil penelitian baik dari buku teks, jurnal maupun artikel, melalui tahapan: 1) Menelaah hasil penelitian karya ilmiah yang terkait. 2) Mengklasifikasikan atau mengelompokkan konsep-konsep terhadap bahan-bahan bacaan. 3) Mendeskripsikan ulang dalam bentuk analisis 4) Menyajikan dalam bentuk tabel atau matriks 5) Mengambil saripati.

\section{Hasil dan Pembahasan}

Seni rupa adalah cabang seni yang menciptakan karya seni dengan media yang bisa dilihat dengan mata dan dapat dirasakan dengan indera peraba. Selain itu seni rupa juga dapat disebut sebagai karya seni yang dapat dinikmati oleh masyarakat umum. Menurut Haukin dalam (Romadecade, 2020), seni rupa adalah bagian dari ekspresi jiwa manusia yang diimajinasikan dan diterapkan kedalam sebuah benda. Haukin berpendapat jika sebuah seni rupa adalah seni yang juga untuk dipamerkan atau dipertunjukkan di depan orang banyak.

Belajar merupakan proses interaksi antar stimulus dan respon yang mungkin berbentuk pikiran, perasaan atau gerakan. Dalam proses pembelajaran seni rupa yang terpenting adalah mengupayakan terciptanya situasi dan kondisi yang kondusif bagi kegiatan belajar yang menyangkut ekspresi artistik dan menciptakan lingkungan yang dapat membantu perkembangan anak untuk menemukan sesuatu melalui eksplorasi dan eksperimentasi dalam belajar. Ismiyanto (2009).

Berdasarkan ragam dan fungsinya seni rupa murni dan seni rupa terapan merupakan bagian dari seni rupa. Seni rupa murni / visual ekspresif memfokuskan karyanya pada nilainilai estetika semata, misalnya benda-benda pajangan atau lukisan dan patung. Sementara 
seni rupa terapan penggunaannya dalam kehidupan sehari-hari memfokuskan karyanya pada nilai estetika yang memperhatikan nilai-nilai praktis.. Seni Murni / Visual Ekspresif lahir dari adanya ungkapan atas ekspresi jiwa, tanpa adanya faktor pendorong untuk tujuan materiil dan bertujuan untuk memenuhi kebutuhan spiritual. (Soedarso, 2000).

Visual adalah dapat dengan indra penglihat (mata), berdasarkan penglihatan. Ekspresif adalah mampu memberikan atau mengungkapkan gambaran, maksud, gagasan, perasaan. (KBBI, 2019). Jadi, visual ekspresif adalah seni visual yang dapat dinikmati melalui media penglihatan (mata) yang mampu memberikan (mengungkapkan) gambaran, maksud, gagasan dan perasaan.

Ada tujuh jenis seni rupa murni / visual ekspresif yaitu, seni lukis, seni patung, seni grafis, seni fotografi, seni instalasi, film/video art dan performance art. Namun dalam artikel ini hanya akan membahas seni lukis saja, lukisan dianggap contoh. karena fungsinya yang sekedar menjadi hiasan dinding atau pajangan. Lukisan merupakan karya seni yang dibuat dengan melukiskan cat warna ke atas media kanvas "2 dimensi". Menurut (Soedarso, 2000) Seni ini memiliki wujud nyata dan pasti, yang mana dapat dilihat secara langsung melalui elemen-elemen berupa gambar, lukisan, multimedia, patung, kerajinan tangan, dan grafis. Seni rupa merupakan seni visual yang dapat dinikmati melalui media penglihatan.

Unsur Visual Ekspresif menurut (Soedarso, 2000) adalah garis, bidang, warna, tekstur, nada gelap dan terang, dan ruang. Garis terbentuk melalui goresan atau tarikan dari titik yang satu ke titik yang lain. Bidang berupa permukaan yang datar. Ada tiga jenis warna dasar, yaitu merah, biru dan kuning. Tekstur adalah permukaan suatu benda, ada yang halus dan ada yang kasar. Nada gelap dan terang, kelihaian menentukan sisi gelap dan sisi terang secara tepat merupakan penggambaran bentuk benda yang baik. Ruang yang diwujudkan dalam gambar dinamakan ruang khayalan (imajiner).

Kegunaan seni rupa visual ekspresif dalam program pendidikan inklusif adalah. (1) Sebagai wujud simbiolisasi rupa melalui ekspresi pribadi dan ungkapan emosional terdalam. (2) Sebagai suatu upaya untuk membangun aktualisasi diri melalui ungkapan estetis untuk memperoleh orisinalitas karya. (3) Merupakan proses penciptaan karya seni yang menyentuh dan bermakna yang diwujudkan melalui perekaman peristiwa. (4) Sebagai sarana untuk membangun komunikasi, imajinasi serta gagasan siswa dalam program pendidikan inklusif. (5) Sebagai terapi kejiwaan, pengayaan jiwa bagi siswa dalam program pendidikan inklusif melalui ketenangan, hiburan, maupun penyehatan rohani.

Proses yang dilakukan pada pembelajaran visual ekspresif dalam program pendidikan inklusif berfungsi sebagai model dalam mengolah aspek kognitif, afektif dan psikomotorik anak, yaitu melatih koordinasi pikiran, perasaan dan aktivitas fisik secara bersamaan. Dengan pembelajaran visual ekspresif, dalam proses pembuatan karya seni anak akan menjadi semakin rileks, karena pada dasarnya visual ekspresif dapat dijadikan 
sebagai wadah bagi siswa program pendidikan inklusif untuk menggali potensi diri, melatih konsentrasi sehingga anak dapat bersosialisasi seperti anak normal pada umumnya. Melalui bentuk-bentuk karya seni visual ekspresif, siswa dapat mempelajari dan mengekspresikan pemahamannya, pengetahuannya, sehingga siswa dapat mengembangkan imajinatif, kreatif serta kecerdasannya.

Interaksi sosial merupakan hubungan timbal balik, baik hubungan antara individu dengan individu, individu dengan kelompok maupun kelompok dengan kelompok. Teori psikoanalisis Sigmund Freud menjelaskan tentang hakikat dan perkembangan kepribadian manusia. Adapun unsur-unsur yang diutamakan dalam teori ini adalah perkembangan motivasi, emosi dan aspek-aspek internal lainnya. (Helaludin dan Syahrul, 2018). Pada dasarnya, siswa inklusif merupakan anak yang memiliki rasa percaya diri rendah, sehingga ketika dia ingin berprestasi dan berkompetisi maka membutuhkan aspek dukungan, dorongan dan motivasi dari orang-orang disekitarnya yaitu guru dan orang tua. Begitupun juga dalam mengikuti pembelajaran visual ekspresif diperlukan motivasi dari guru dan orang tua siswa inklusif.

Tabel 1. Perkembangan Penelitian tentang Kajian Visual Ekspresif dalam Pendidikan Inklusif

\begin{tabular}{|c|c|c|c|c|}
\hline \multirow{2}{*}{ No } & \multirow{2}{*}{ Aspek } & \multicolumn{3}{|c|}{ Periodisasi } \\
\hline & & $2009-2012$ & 2013 - 2016 & 2017 - 2020 \\
\hline 1. & $\begin{array}{l}\text { Objek / } \\
\text { Masalah } \\
\text { Penelitian }\end{array}$ & $\begin{array}{l}\text { Peningkatan hasil belajar } \\
\text { menggambar ekspresi } \\
\text { melalui metode ekspresi } \\
\text { bebas (Zufrida, 2012) }\end{array}$ & $\begin{array}{l}\text { Pengembangan program } \\
\text { layanan pendidikan } \\
\text { inklusif (Restu. 2015) }\end{array}$ & $\begin{array}{l}\text { Menggunakan seni visual untuk } \\
\text { mendorong anak-anak dengan } \\
\text { gangguan spektrum autisme } \\
\text { untuk mengkomuniakasikan } \\
\text { perasaan dan emosi mereka } \\
\text { (Round, 2017) }\end{array}$ \\
\hline & $\begin{array}{l}\text { Metode } \\
\text { Penelitian }\end{array}$ & $\begin{array}{l}\text { Penelitian Tindakan Kelas } \\
\text { (PTK) }\end{array}$ & $\begin{array}{l}\text { Metode Deskriptif } \\
\text { dengan pendekatan } \\
\text { Kualitatif }\end{array}$ & $\begin{array}{l}\text { Metode Deskriptif dengan } \\
\text { pendekatan Kualitatif }\end{array}$ \\
\hline & $\begin{array}{l}\text { Hasil Guna } \\
\text { Penelitian }\end{array}$ & $\begin{array}{l}\text { Deskripsi tentang } \\
\text { - Adanya peningkatan } \\
\text { hasil belajar seni rupa } \\
\text { yang sangat } \\
\text { memuaskan. } \\
\text { - Guna penelitian } \\
\text { secara teoritis untuk } \\
\text { pengembangan riset } \\
\text { dan keilmuan juga } \\
\text { secara praktis adalah } \\
\text { untuk membangun } \\
\text { pemahaman bagi guru } \\
\text { dalam bidang seni } \\
\text { rupa di sekolah dasar. }\end{array}$ & $\begin{array}{l}\text { Deskripsi tentang } \\
\text { - Ketidakmerataan } \\
\text { pemahaman guru } \\
\text { tentang pendidikan } \\
\text { inklusif, sehingga } \\
\text { pembelajaran bagi } \\
\text { siswa ABK masih } \\
\text { terkotak-kotak. } \\
\text { - Kompetensi yang } \\
\text { dimiliki guru } \\
\text { pendamping tidak } \\
\text { memenuhi kriteria, } \\
\text { serta koordinasi yang } \\
\text { belum terjalin antara } \\
\text { guru dan tim IEP. } \\
\text { Guna penelitian } \\
\text { untuk meningkatkan } \\
\text { professionalitas guru. }\end{array}$ & $\begin{array}{l}\text { Deskripsi tentang } \\
\text { - } \text { Pembelajaran seni } \\
\text { berdampak pada komunikasi } \\
\text { perasaan dan emosi anak } \\
\text { dengan Autism Spectrum } \\
\text { Disorder (ASD). } \\
\text { - Guna penelitian secara } \\
\text { teoritis untuk } \\
\text { pengembangan riset dan } \\
\text { keilmuan juga secara praktis } \\
\text { adalah untuk membangun } \\
\text { pemahaman bagi guru } \\
\text { dalam bidang seni rupa di } \\
\text { sekolah inklusif. }\end{array}$ \\
\hline
\end{tabular}




\begin{tabular}{|c|c|c|c|c|}
\hline \multirow{2}{*}{ No } & \multirow{2}{*}{ Aspek } & \multicolumn{3}{|c|}{ Periodisasi } \\
\hline & & $2009-2012$ & $2013-2016$ & $2017-2020$ \\
\hline 2. & $\begin{array}{l}\text { Objek / } \\
\text { Masalah } \\
\text { Penelitian }\end{array}$ & & $\begin{array}{l}\text { Mendeskripsikan } \\
\text { Kekhasan Karya Lukis } \\
\text { Anak Berkebutuhan } \\
\text { Khusus di Sekolah } \\
\text { Inklusif kelas IX H SMPN } \\
2 \text { Sewon Yogyakarta ( } \\
\text { Wardhana, 2014) }\end{array}$ & $\begin{array}{l}\text { Pengaruh pendidikan seni rupa } \\
\text { pada anak dengan Gangguan } \\
\text { Spektrum Autisme (Cevirgen, } \\
\text { 2018) }\end{array}$ \\
\hline & $\begin{array}{l}\text { Metode } \\
\text { Penelitian }\end{array}$ & & $\begin{array}{l}\text { Metode deskriptif } \\
\text { dengan pendekatan } \\
\text { Kualitatif }\end{array}$ & - Pendekatan Kualitatif \\
\hline & $\begin{array}{l}\text { Hasil Guna } \\
\text { Penelitian }\end{array}$ & & $\begin{array}{l}\text { Deskripsi tentang } \\
\text { - Karakteristik serta } \\
\text { kekhasan karya lukis } \\
\text { ABK berpengaruh } \\
\text { pada hasil lukisan } \\
\text { yang memiliki } \\
\text { imajinasi tinggi, juga } \\
\text { penuh ekspresi pada } \\
\text { bentuk dan warna. } \\
\text { - Guna penelitian } \\
\text { secara teoritis untuk } \\
\text { pengembangan riset } \\
\text { dan keilmuan juga } \\
\text { secara praktis adalah } \\
\text { untuk membangun } \\
\text { pemahaman bagi } \\
\text { guru dalam bidang } \\
\text { seni rupa di sekolah } \\
\text { inklusif. }\end{array}$ & $\begin{array}{l}\text { Deskripsi tentang } \\
\text { - Setelah pelajaran seni rupa, } \\
\text { anak-anak dengan ASD } \\
\text { merasa lebih bahagia dan } \\
\text { damai. Juga meningkatkan } \\
\text { kepercayaan diri serta } \\
\text { imajinasi mereka. } \\
\text { - Guna penelitian secara } \\
\text { teoritis untuk } \\
\text { pengembangan riset dan } \\
\text { keilmuan juga secara praktis } \\
\text { adalah untuk membangun } \\
\text { pemahaman bagi guru } \\
\text { dalam bidang seni rupa di } \\
\text { sekolah inklusif. }\end{array}$ \\
\hline
\end{tabular}

\begin{tabular}{ll}
\hline 3. Objek/ & Mendeskripsikan pendidikan \\
Masalah & seni budaya dan prakarya \\
senelitian & sebagai strategi intervensi \\
& Kmum bagi Anak Berkebutuhan \\
& Khusus (Mareza 2017) \\
\hline Metode & Metode Deskriptif dengan \\
Penelitian & pendekatan Kualitatif \\
\hline Hasil Guna & Deskripsi tentang \\
Penelitian & Bahwa pendidikan seni \\
& sebagai sarana dalam \\
& pengembangan karakter \\
& pribadi yang berlandaskan \\
& sosial budaya, juga \\
& berfungsi sebagai \\
& pengembangan \\
& pengetahuan dan \\
& keterampilan, \\
& Hasil dan guna secara \\
& teoritis untuk \\
& pengembangan riset dan \\
& keilmuan juga secara praktis \\
& adalah untuk membangun
\end{tabular}




\begin{tabular}{|c|c|c|c|}
\hline \multirow{2}{*}{ No } & \multirow{2}{*}{ Aspek } & \multicolumn{2}{|c|}{ Periodisasi } \\
\hline & & $2009-2012$ & $2017-2020$ \\
\hline 4. & $\begin{array}{l}\text { Objek / } \\
\text { Masalah } \\
\text { Penelitian }\end{array}$ & & $\begin{array}{l}\text { Pembelajaran seni rupa untuk } \\
\text { anak berkebutuhan khusus } \\
\text { jenjang SMA di SLB Perwari } \\
\text { Ulak Karang (Susanto, 2018) }\end{array}$ \\
\hline & $\begin{array}{l}\text { Metode } \\
\text { Penelitian }\end{array}$ & & $\begin{array}{l}\text { Metode Deskriptif dengan } \\
\text { pendekatan Kualitatif }\end{array}$ \\
\hline & $\begin{array}{l}\text { Hasil Guna } \\
\text { Penelitian }\end{array}$ & & $\begin{array}{l}\text { Deskripsi tentang } \\
\text { - Menjelaskan mengenai } \\
\text { proses anak berkebutuhan } \\
\text { khusus dalam pembelajaran } \\
\text { seni rupa jenjang SMA di } \\
\text { SLB. } \\
\text { - Hasil guna penelitian untuk } \\
\text { meningkatkan } \\
\text { professionalitas guru dalam } \\
\text { pembelajaran seni rupa } \\
\text { jenjang SMA bagi Anak } \\
\text { Berkebutuhan Khusus di } \\
\text { SLB. }\end{array}$ \\
\hline 5. & $\begin{array}{l}\text { Objek / } \\
\text { Masalah } \\
\text { Penelitian }\end{array}$ & & $\begin{array}{l}\text { Mendeskripsikan kegiatan seni } \\
\text { terapeutik di semata galerry } \\
\text { pada anak disleksia (Tia A.R, } \\
\text { 2018) }\end{array}$ \\
\hline & $\begin{array}{l}\text { Metode } \\
\text { Penelitian }\end{array}$ & & $\begin{array}{l}\text { Metode Eksperimen yang } \\
\text { ditulis secara deskriptif }\end{array}$ \\
\hline & $\begin{array}{l}\text { Hasil Guna } \\
\text { Penelitian }\end{array}$ & & $\begin{array}{l}\text { Penelitian ini mendeskripsikan } \\
\text { tentang visualisasi karya anak } \\
\text { berupa ekspresi wajah pada } \\
\text { objek gambar anak disleksia } \\
\text { yang menggunakan warna tonal } \\
\text { dramatis dan gelap yaitu } \\
\text { merah, orange, dan hitam, serta } \\
\text { goresan yang cenderung acak- } \\
\text { acakan dan abstrak sehingga } \\
\text { membuat kesan seram, takut } \\
\text { dan sedih. }\end{array}$ \\
\hline
\end{tabular}

Dalam pembelajaran visual ekspresif, dilakukan transfer pengetahuan, meningkatkan kemampuan artistik, memperkaya literasi visual, eksplorasi emosi dan perasaan, mengembangkan kreativitas, meningkatkan self-esteem (rasa percaya diri), sehingga akan menghasilkan karya visual ekspresif sesuai dengan curahan emosi dan perasaannya. Perkembangan penelitian tentang kajian visual ekspresif dalam pendidikan inklusif disajikan pada Tabel 1.

\section{Kesimpulan}

Proses pembelajaran visual ekspresif dalam program pendidikan inklusif memberikan bimbingan dan informasi agar anak-anak memiliki pengetahuan tentang banyak hal baik definisi, unsur dan kegunaan pembelajaran visual ekspresif dalam program pendidikan inklusif.

Pembelajaran visual ekspresif dalam program pendidikan inklusif merupakan cara yang efektif untuk mengekspresikan diri anak-anak terutama untuk mengungkapkan 
perasaan mereka dalam berkarya sehingga memberikan kesempatan bagi mereka untuk mengembangkan fleksibilitas, harga diri dan perilaku komunikasi sosial, juga mengekspresikan perasaan dan emosi mereka dengan lebih baik sehingga dapat meningkatkan kualitas hidup bagi mereka disamping meningkatkan kreativitas dalam berkarya. Kegiatan berapresiasi, berekspresi, serta memiliki makna dalam kehidupan sehari-hari dalam bentuk pengetahuan, keterampilan dan sikap.

\section{Daftar Pustaka}

Tia, A.R. (2018). Kegiatan seni terapeutik di semata galerry pada anak disleksia. Bandung: Institut Teknologi Bandung. Diterima melalui https://digilib.itb.ac.id/index.php/gdl/view/31295 pada tanggal 05 Agustus 2020

Cevirgen, Ayse. (2018). Pengaruh pendidikan seni rupa pada anak dengan gangguan spektrum autisme (ASD). Researchgate.net. Diterima melalui https://www.researchgate.net/publication/323259290_The_Infulence_of_Visual_Arts_ Education_on_children_With_ASD pada tanggal 05 Agustus 2020

Helaludin \& Syahrul, S. (2018). Psikoanalisis sigmund freud dan implikasinya dalam pendidikan. Banten: UIN Sultan Maulana Hasanuddin. Researchgate.net. Diterima melalui

https://www.researchgate.net/publication/323535054_Psikoanalisis_Sigmund_Freud_ dan_Implikasinya_dalam_Pendidikan/link/5a9a57750f7e9be379640c45/download pada tanggal 05 Agustus 2020

Irawan, P. dan Suciati, W. (1997). Teori belajar, motivasi dan keterampilan mengajar bahan ajar program pengembangan keterampilan dasar teknik instruksional untuk dosen muda. Jakarta. Universitas Terbuka.

Ismiyanto, P S. (2009). Perencanaan pembelajaran seni rupa. GBPP-silabus, RPP, dan handout mata kuliah jurusan seni rupa. FBS Unnes. Jurusan Seni Rupa.

Kamaril, C. (2000). Pendidikan seni rupa/ kerajinan tangan. Universitas Terbuka. Jakarta.

Kamus Besar Bahasa Indonesia (2019).Penjelasan visual, ekspresif. Diterima melalui www.kbbi.web.id pada tanggal 05 Agustus 2020

Mareza, L. (2017). Pendidikan seni budaya dan prakarya (SBdP) sebagai strategi intervensi umum bagi anak berkebutuhan khusus. Researchgate.net https://www.researchgate.net/publication/315301093_Pendidikan_Seni_Budaya_dan _Prakarya_SBdP_Sebagai_Strategi_Intervensi_Umum_Bagi_Anak_Berkebutuhan_K husus

Mareza, L. (2018). strategi model pembelajaran seni rupa bagi anak berkebutuhan khusus. Purwokerto: Universitas Muhammadiyah. Diterima melalui http://jurnal.univrab.ac.id/index.php/psi/article/view/511 pada tanggal 06 Agustus 2020

Pamadhi. H (2012). Seni keterampilan anak. Tanggerang Selatan: Universitas Tebuka

Restu, Vika. (2015). Pengembangan program layanan pendidikan inklusif. Diterima melalui http://repository.upi.edu/21070/ pada tanggal 06 Agustus 2020

Romadecade, (2020). Pengertian seni rupa. Romadecade.org. diterima melalui https://www.romadecade.org/pengertian-seni-rupa/\#! pada tanggal 12 Agustus 2020

Round, Alicia. (2017). Menggunakan seni visual untuk mendorong anak - anak dengan 
gangguan spektrum autisme untuk mengkomuniskasikan perasaan dan emosi mereka. Researchgate.net. Diterima melalui https://www.researchgate.net , publication > 320 pada tanggal 06 Agustus 2020

Restu, V. (2015). Pengembangan program layanan pendidikan inklusif. Diterima melalui http://repository.upi.edu/21070/ pada tanggal 06 Agustus 2020

Simanis. (2019). Seni rupa murni pengertian fungsi contoh seni rupa murni dan gambarnya. Diterima melalui https://www.pelajaran.co.id/2019/15/seni-rupa-murni.html pada tanggal 06 Oktober 2020

Soedarso S.P. (2000). Sejarah perkembangan seni rupa modern. Jakarta: Studio Delapan Puluh Enterprise bekerja sama dengan Badan Penerbit ISI Yogyakarta.

Sukardi. (2013). Metodologi penelitian pendidikan kompetensi dan praktiknya. PT Bumi Aksara: Jakarta.

Susanto, Didi. (2018). Pembelajaran seni rupa untuk anak berkebutuhan khusus jenjang SMA di SLB Perwari Ulak Karang. Repository unp. Diterima melalui http://repository.unp.ac.id/21668/ pada tanggal 06 Agustus 2020

UNESCO. (2006). Deklarasi dunia tentang pernyataan salamanca pendidikan untuk semua jomtien tahun 1990 kompendium perjanjian, hukum, dan peraturan menjamin semua anak memperoleh kesamaan hak untuk kualitas pendidikan dalam cara inklusif. Jakarta: UNESCO Office.

Wardhana, A.D. (2014). Kekhasan karya lukis anak berkebutuhan khusus di sekolah inklusif. [Online]. Diterima melalui http://eprints.uny.ac.id/20547/ pada tanggal 06 Agustus 2020

Wiratna, N. Sujarweni. (2014). Metodelogi penelitian. Pustaka Baru Perss: Yogyakarta.

Zufrida, Vella. (2012). Peningkatan hasil belajar menggambar ekspresi melalui metode ekspresi bebas pada siswa kelas II SD negeri 02 pesucen Kabupaten Pemalang. Digilib Unnes : Universitas Negeri Semarang. [Online] Diterima melalui https://lib.unnes.ac.id/18171/ pada tanggal 06 Agustus 2020 